\title{
RETRENCHMENT, REFORM OR REVOLUTION? THE SHIFT TO INCENTIVES AND THE FUTURE OF THE REGULATORY STATE
}

\section{ROBERT HOWSE*}

A shift to incentive-based instruments of regulation is often viewed as a solution to the defects and limits of the traditional regulatory state. This article argues that, although in some contexts incentive-oriented approaches are desirable, there are limits to the use of economics in the regulatory process, particularly with respect to defining the goals of regulation in a pluralist democracy. As well. traditional policy instruments can be altered. evolved or supplemented to allow for better government. There are many ways that government can bring about basic social change that neither suggest a retum to old command and control approaches nor an increased reliance on or deference to economically self-interested market behaviour. It is these alternative approaches that are most promising for advancing the unfinished agenda of the social welfare state, through a better reconciliation of care with autonomy and choice with community.

\section{TABLE OF CONTENTS}

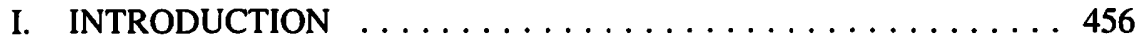

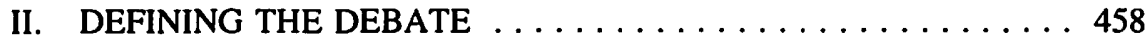

III. THE SHIFT TO INCENTIVES AND

THE NORMATIVE ASSUMPTIONS OF

REGULATORY APPROACHES $\ldots \ldots \ldots \ldots \ldots \ldots \ldots \ldots 460$

A. SELF-INTEREST, ALTRUISM,

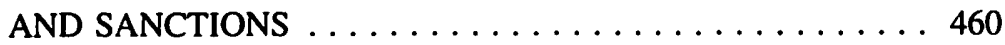

B. SETTING OF PUBLIC GOALS UNDER

COMMAND-AND-CONTROL APPROACHES $\ldots \ldots \ldots \ldots 463$

C. INCENTIVE INSTRUMENTS AND

ALTERNATIVE, MARKET-BASED

APPROACHES TO GOAL-SETTING . . . . . . . . . . 464

D. CHARACTERIZING AND MEASURING SOCIAL

COSTS UNDER MARKET-BASED APPROACHES . . . . . 467

E. PROPERTY RIGHTS OR BURDENS

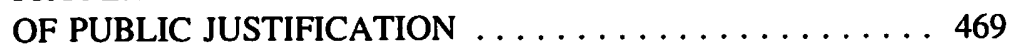

F. REDISTRIBUTIVE CONSIDERATIONS

AND THE SHIFT TO INCENTIVES $\ldots \ldots \ldots \ldots \ldots \ldots 471$

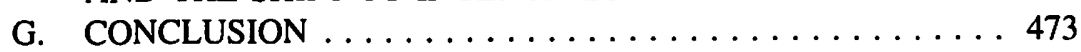

IV. DILEMMAS, PARADOXES, AND COMPLEXITIES

IN THE DESIGN AND IMPLEMENTATION OF

INCENTIVE INSTRUMENTS $\ldots \ldots \ldots \ldots \ldots \ldots \ldots \ldots 474$

Assistant Professor of Law and Assistant Director, International Business and Trade Law Programme, Faculty of Law, University of Toronto.

I wish to thank the following individuals for advice, encouragement and ideas: David Cohen, Denyse Goulet, Linda Duncan, Hudson Janisch. Richard Janda, Rob Prichard. My colleagues Ron Daniels and Michael Trebilcock read earlier drafts of this paper with painstaking care, as did Lisa Freeman and Cass Sunstein their help was indispensable. $I$ also benefitted from comments from a variety of participants in the Power of the Purse Conference at which this paper was initially given. 
A. COMPLIANCE COSTS AS AGENCY COSTS ........ 474

B. CONFLICTING INTERESTS AND

INCENTIVES WITHIN REGULATED ENTITIES . . . . . . 477

C. SELF-DEFEATING OR PERVERSE INCENTIVE

ASPECTS OF INCENTIVE INSTRUMENTS . . . . . 478

D. THE DANGERS OF OVER-RELIANCE UPON

AXIOMATIC ASSUMPTIONS ABOUT ECONOMIC

SELF-INTEREST . . . . . . . . . . . . . . . . 479

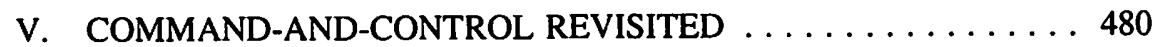

A. INTRODUCING FLEXIBILITY INTO

COMMAND-AND-CONTROL APPROACHES $\ldots \ldots \ldots \ldots 480$

B. REPLACING OLD COMMAND-AND-CONTROL

INSTRUMENTS WITH BETTER-TARGETED

OR FINER TUNED INSTRUMENTS $\ldots \ldots \ldots \ldots \ldots \ldots 481$

C. INCENTIVE INSTRUMENTS THAT WORK

BEST IN CONJUNCTION WITH NEW

COMMAND-AND-CONTROL INSTRUMENTS $\ldots \ldots \ldots 482$

VI. ECONOMIC INCENTIVES AND THE LIMITS

AND POSSIBILITIES OF SOCIAL TRANSFORMATION $\ldots \ldots \ldots 483$

A. GOVERNMENT, MARKETS, AND

SOCIAL CHANGE . . . . . . . . . . . . . . 483

B. WITHOUT LENIN, SMITH OR KEYNES

ALTERNATIVE IMAGES AND MEANS

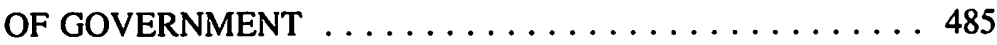

C. TAKING THE SOCIAL WELFARE STATE

BEYOND THE REGULATORY REFORM DEBATE

ASSOCIATION, AUTONOMY AND CARE . . . . . . 487

VII. CONCLUSION: RETRENCHMENT,

REFORM OR REVOLUTION? . . . . . . . . . . . . . 492

\section{INTRODUCTION}

Among the most common descriptions of the trend toward regulatory reform, or "deregulation," characteristic of government policy-making over the last 20 years, is that of a shift from command-and-control regulation towards the use of economic incentive-based instruments. In a recent article, "Smaller or Smarter Government?,"1 some associates and I tended towards the adoption of such a characterization, albeit with a significant number of qualifications and nuances.

Our intent was to persuade administrative lawyers, particularly those dedicated to strong, progressive government, that they should react to the critique of traditional instruments of government intervention neither with alarm nor defeatism. Although often packaged as "smaller government," reforms such as privatization, deregulation and tax

R. Howse, J.R.S. Prichard \& M.J. Trebilcock, "Smaller or Smarter Government" (1990) 4 U.T.L.J. 478. 
reform, really held out the prospect of "smarter government" - more effective, as well as more efficient, realization of liberal and social democratic objectives and norms through the use of an alternative, "market-friendly" set of policy instruments. Not dissimilar perspectives have been expressed by prominent American administrative lawyers with an unquestioned commitment to government that is both strong and progressive, among them Cass Sunstein ${ }^{2}$ and Susan Rose-Ackerman. ${ }^{3}$

But just as rejection of the market-oriented reforms would have been an inappropriate response, there is now an equal and opposite danger of a too automatic and unqualified embrace of "rules to incentives," either as a description of what has happened, or as an overarching prescription for the new administrative law. The replacement of a traditional bias toward "rules" with a new bias toward "incentives" may cause many opportunities for improved regulation to be overlooked, and in oversimplifying what is at stake in the design and choice of policy instruments, may lead to very costly errors. This in turn raises the danger of an early disappointment with the experiment in regulatory redesign that could entail either a call for a return to traditional, ineffective approaches, or worse still - a kind of defeatism or cynicism about the capabilities of government in general.

This essay is aimed at moving the debate about instrument choice and regulatory reform beyond the "rules vs. incentives" dichotomy.

Part II attempts to elaborate the defining characteristics of command-and-control and incentive instruments respectively, as they are presented in the debate.

In Part III, I build upon this discussion of definitions and concepts, and attempt to elucidate some of the fundamental normative assumptions that underlie different approaches to the achievement of public ends. I argue that the choice between responding to social harms by prohibitive sanctions and stigmatization on the one hand or by harnessing economic self-interest on the other, oversimplifies both the motivations of human agents and the appropriate posture of the state towards individual and collective preferences.

Part IV explores a number of respects in which the use of incentive instruments can involve complex choices about instrument design, how problems of compliance under command-and-control become agency cost problems once there is a shift to incentives, and how determination of the incentive effects of incentive-based policies is often a complicated exercise, which requires an understanding of conflicting interests within regulated entities, and which may suffer by overly relying upon axiomatic assumptions about economically self-interested behaviour.

In Part V, I elaborate on a number of areas where opportunities for better government are available by reshaping traditional command-and-control instruments, by creating new command-and-control instruments that work hand in hand with incentive instruments, or 
substituting new and better command-and-control instruments for old ones. Again my intent is to show that while the possibilities offered by a shift toward incentive-oriented instruments are unquestionably of high importance to the prospects for smarter government, they are still only part of the story.

Part VI focuses on policy instruments that fit neither into the traditional command-and-control category nor depend upon market mechanisms in the way in which incentive-based instruments are purported to do. These instruments evoke a role for the state in shaping society by enhancing or facilitating social action by individuals and groups, by educating citizens, and enabling new forms of association, solidarity, and citizen participation that simultaneously strengthen both community and autonomy.

\section{DEFINING THE DEBATE}

During the last two decades, the regulatory state in North America has come under persistent attack for not achieving its stated objectives, whether the management of and reduction of environmental harm, the elimination of workplace risks, or the reduction of poverty. In some instances, regulation has been faulted for excessive "interference" in markets, and for imposing burdens on the private sector that threaten economic prosperity and growth. While, as Cass Sunstein suggests, certain of these attacks have invoked "crude or facile beliefs in private ordering and private markets," ${ }^{4}$ others have focused, ostensibly, on the purported negative features of the typical instruments of intervention employed by the post-New Deal regulatory state. The latter have accompanied this critique with proposals not for regulatory retreat or retrenchment but for employment of an alternative set of policy instruments able to achieve stated objectives at lower cost, and with less harmful interference in market outcomes, i.e. for smarter, rather than smaller government. $^{\mathrm{s}}$

The thrust of this critique is well-summarized by Richard Stewart:

The current system of command regulation, which requires tremendous centralization of information and decisionmaking, is generally far more costly for the government to administer than alternatives that place greater reliance on market incentives... The command and control approach penalizes investment and innovation because of high compliance costs, the restrictions imposed by uniform, inflexible directives, and the delay and uncertainty created by protracted litigation and administrative licensing and standard-selting proceedings.... Greater use of market-based and other reconstitutive strategies will be needed in order to reduce compliance burdens and encourage diversity, flexibility, and innovation on the part of businesses, consumers, non-profit organizations, and state and local governments. ${ }^{6}$

Implicit in this perspective is something like the following contrast between the typical characteristics of command-and-control and of incentive instruments. 
Command-and-control regulation:

a) seeks to achieve very general public goals by extremely detailed, regulator-driven rules, standards, and procedures that "require or proscribe specific conduct by regulated firms";

b) is enforced through coercive (e.g. injunctions) or punitive (e.g. fines) state action, generally considered to entail substantial compliance costs;

c) is "direct," in the sense that it seeks to achieve redistributive goals, or the internalization of social costs from economic activity through the setting of rates or prices, or mandating of detailed standards that directly interferes with, or distorts, the allocation of resources by markets; and

d) is highly centralized and places the direction of activity in the hands of typically large and complex bureaucratic structures.

By contrast, incentive-based regulation:

a) mandates only the public goals themselves and, to a greater or lesser extent, leaves wide play to market incentives in determining the way that regulated entities go about achieving these objectives;

b) is largely self-enforcing, because instead of monitoring and enforcing compliance with an enormous number of detailed rules, regulators need only assure that the overall conduct of the regulated entity complies with public goals, or that the appropriate tax or charge on harmful activity is paid;

c) achieves redistributive goals through taxes and transfers, not setting of prices and rates (e.g. subsidies for housing to lower-income tenants rather than controlled rents), and instead of selectively prohibiting harmful activity sets an appropriate price on it that assures the internalization of social costs;

d) functions largely through existing private decision-making systems, achieving important public goals without the need to create bureaucratic structures that engender dependency on government actors to direct activity in detail; and

e) influences the behaviour of existing institutional actors, or individuals within existing social structures, while seeking to alter as little as possible private preferences themselves, or the deep structure of society and economy.

In determining whether a shift from command-and-control to incentive instruments is warranted, policymakers must consider a broad range of questions, questions that go beyond the generic classification and contrast of policy instruments suggested by the above taxonomy. First of all, the specific characteristics of the traditional instruments that have created regulatory failure must be identified. It should not be assumed, for instance, that problems of inflexible or arbitrary standards, or compliance problems indicate a failure of command-and-control instruments as such. Secondly, it is necessary to analyze whether, if deployed in the particular context envisaged, incentive instruments would or would not display the generic properties described above. As will be discussed below, 
some incentive-based schemes involve compliance and administrative costs and complications that equal, or even exceed, those of command-and-control regulation (even if other factors may still argue for their adoption).

\section{THE SHIFT TO INCENTIVES AND THE NORMATIVE ASSUMPTIONS OF REGULATORY APPROACHES}

To what extent does a shift to incentive instruments represent a "fine-tuning" of existing regulations, and to what extent does it represent a repudiation or alteration of the traditional norms of the regulatory state? As Cook notes in the context of regulation of air pollution in the United States, "beneath the quarrels over legality, technique and administrative practice lay sharp ideological differences regarding... the introduction of incentive-based regulatory schemes.... ${ }^{18}$ The choice between command-and-control and incentives does implicate basic assumptions about the relationship between individual and collective preferences, the moral character of particular wrongs, and the kinds of human qualities and motivations that should be encouraged (or discouraged) by policymakers. This usually makes a choice between instruments more complex than is often suggested by either the advocates or the critics of incentive-based approaches.

\section{A. SELF-INTEREST, ALTRUISM, AND SANCTIONS}

At its most abstract level, the case for use of incentives in the regulatory process appears to rest on the legitimacy and desirability of harnessing or channelling self-interest for public ends. Advocates of incentives, such as Charles Schultze, implicitly or explicitly present themselves as heirs of early modern thinkers, such as Adam Smith and Bernard Mandeville, ${ }^{10}$ who argued contrary to the classical and Christian natural justice traditions that the public good could be best achieved by emancipating material self-interest rather than suppressing or sublimating it - that love of one's own good, and not the common good, was the more reliable foundation for making individual behaviour conform to collective ends.

The case for working with, not against, private preferences and sentiments was made eloquently by Montesquieu: "C'est en vain qu'une morale austere veut éffacer les traits que le plus grand de tous les ouvriers a imprimé dans nos ames. C'est à la morale, qui veut travailler sur le coeur de l'homme, à regler ses sentiments, et non pas à les détruire."II

At issue in the debate is not just the efficacy of relying on self-interest rather than virtue, but the negative and positive side-effects of approaches that rely largely on one or the other. When Schultze praises "market-like arrangements" because they reduce the "need for compassion, patriotism, brotherly love, and cultural solidarity as motivating forces" he does so because these are in short supply.

B. Cook, Bureaucratic Politics and Regulatory Reform (Westport, Conn.: Greenwood, 1988) at 102. C.L. Schultze, The Public Use of Private Interest (Washington D.C.: Brookings, 1977).

B. Mandeville, The Fable of the Bees; or Private Vices, Public Virtues (Oxford: Clarendon, 1924). "Mes Pensées" Ouevres complètes, Vol. I, (Paris: Gallimard, 1949) at 993. 
It has been argued in reply, by Titmuss for instance, ${ }^{12}$ that in relying upon self-interest, governments further reduce the supply of these virtues, or weaken or neglect the social structures required to foster them. The view that self-interest is the only reliable foundation of the public good can then threaten to take on the character of a self-fulfilling prophecy.

But it is not just a question of whether self-interest is to be preferred because of its reliability. Some classic advocates of self-interest, for example, emphasize that the production of traditional virtue or dutifulness may itself have negative side-effects. Often these traits may go hand in hand with moral absolutism or religious fanaticism, thus actually threatening the social order. ${ }^{13}$ Stephen Holmes notes that "nonselfish, but nonetheless murderous behaviour abounds in history. ${ }^{14}$

Other authors focus on the positive effects of non-materialistic motivations, evoking images of spontaneous altruism, not duty imposed by an austere religious or civic moralism. ${ }^{15}$

Steven Kelman argues that a command-and-control system of regulation is more consistent with preservation of altruistic or other ethical, "spontaneous" motivations for actions that sustain the common good. ${ }^{16}$ According to Kelman, "while economic incentives require only self-interested motives, compliance with legal demands, among most citizens, is usually predicated on a wider range of motivations." ${ }^{17}$ Moreover, Kelman argues prohibition through enforcement of rules is consistent with moral stigmatization of conduct, whereas use of economic incentives to limit it has the effect of legitimizing the behaviour in question provided its social costs are paid for.

Frequently, however, command-and-control regulation has prohibited activity, without either enforcing vigorously the prohibition or accompanying it with an adequately severe penalty. It is, to say the least, questionable whether this actually provides greater stigmatization than an effectively monitored and enforced system of substantial taxes and charges.

A further complication is that much regulation is targeted at private firms. According to the normative theory of the firm that prevails in Canadian and American law, corporations are supposed to act solely with a view to maximization of shareholder wealth within, of course, the explicit constraints imposed by contractual obligations to other

R. Titmuss, The Gift Relationship: from Human Blood to Social Policy (London: C. Allenad University, 1970).

See, particularly, Montesquieu's discussion of Sparta in The Spirit of the Laws in supra note 11 Vol. 2. Bk. 4 c.6.

S. Holmes, "The Secret History of Self-Interest" in J. Mansbridge, ed., Beyond Self-Interest (Chicago: Univ. Chicago Press, 1990).

See S. Kelman, What Price Incentives? Economists and the Environment (Boston: Auburn House, 1985) ch. 2, "ethical aspects".

lbid. at 292.

lbid. 
stakeholders, such as employees, debtholders, and trade creditors. ${ }^{18}$ Under this view, firms as institutions do not possess a "social conscience"; although, in determining whether to obey the law, they may calculate the harmful reputational effects of non-compliance (e.g. consumer boycotts, etc.), intrinsic moral or altruistic motivations do not come into play. ${ }^{19}$

More generally, both command-and-control and incentive-based regulation can reinforce altruistic conduct. As Mansbridge suggests, "while duty and love, the two forms of altruism or non-selfish motivation, are valuable in themselves they must also be sustained by institutions or an environment that prevents actions based on them from being excessively costly. ${ }^{20}$ One can easily imagine situations where many individuals will refrain from altruistic conduct because of a belief that others will act selfishly in such a way as to spoil or negate the benefits of altruism.

Consider the example of littering. In a street or park where litter is everywhere, even an environmentally-conscious person may reason that her not littering will have no effect on the ultimate outcome. In a litter-free area, however, a person not normally bothered by littering may in fact feel a sense of shame about doing so. Government, either by doing some clean up itself and/or by sanctioning die-hard litterers, can provide a powerful enforcement to the altruistic or virtuous conduct of many individual citizens.

Here, it is to be noted, an economist who tends to assume that conduct is rationally self-interested would probably view the government clean-up as likely to reduce incentives for individuals not to litter, since they can externalize the costs of littering onto the taxpayers in general through the government. Moral hazard arguments of this nature have been used by critics of traditional regulation to suggest that such regulation may well create perverse incentives, or behavioral effects that are just the opposite of those that the regulation is intended to produce, given the nature of self-interested behaviour. ${ }^{21}$ Contrary to these axioms, recent empirical evidence suggests that government-mandated safety precautions do not result in lower levels of care on the part of individual actors. With respect to seat belt regulation, for example, Friedland, Trebilcock and Roach note: "A number of studies show that people wearing seat-belts do not drive less carefully than others." ${ }^{22}$

J. Ziegel et al., Cases and Materials on Partnerships and Companies, Business Corporations, vol. 1 (Toronto: Carswell, 1980) at 302.

19.

21. See for example, W.K. Viscusi, "Consumer Behaviour and the Safety Effects of Product Safety Regulation" (1985) $28 \mathrm{~J}$. of Law and Econ. 527 and compare M. Kelman, "Democracy Bashing" (1988) 74 Va. L. Rev. 199 at 245-251.

22. M. Friedland, M.J. Trebilcock \& K. Roach, Regulating Traffic Safety (Toronto: University of Toronto Press, 1990) at 38. 
Finally, it is an over-simplication to identify self-interest with economic self-interest, or all non-economic behaviour with altruism. Motivations such as pride and honour are also self-interested they are other-directed only in the attenuated sense that they look toward others' recognition or approval of our actions. Compassion directs us to care for others, but it can also be understood as an indulgence of our sentiments. ${ }^{23}$ Similarly, individuals may preoccupy themselves with the acquisition of wealth primarily to benefit their family, or advance the causes they believe in. ${ }^{24}$

\section{B. SETTING OF PUBLIC GOALS UNDER COMMAND-AND-CONTROL APPROACHES}

The moral imperatives that have driven the expansion of the regulatory state have been fuelled by the recognition of certain evils, produced by or at least tolerated by the untrammelled marketplace - the laying to waste of the natural horizon in which we live our lives, the avoidable death and misery of the unsafe working place, the carnage on the highways from human carelessness and technological failure. Compassion, a sense of our mutual vulnerability and indignation at injustice, has been a powerful motivation for regulation, not revolution in liberal democracies. ${ }^{25}$

Over the last twenty years, economists have developed a language in which regulation has been scrutinized and justified that is quite different from the language of justice, rights, and compassion, a language that has its normative roots in a utilitarian view of the public purpose. Regulation is characterized as a response to market failures, to the external economic costs of private transactions, and above all, to the gap between private and social costs of a particular economic activity. ${ }^{26}$

Mark Plattner has noted "the hegemony of economics over the new discipline of policy analysis. Not only academic journals but legislative chambers and op-ed pages are filled with the language and concepts economists have brought to the discussion of public policy - costs and benefits, trade-offs, efficiency, maximization, optimal solutions, market mechanisms, externalities, public goods, incentives and disincentives, etc."27

What is the root cause of the ascendency of economic analysis in regulatory theory?

As the regulatory state matured, it became increasingly apparent that the moral languages of rights, justice, and compassion do not easily translate into coherent policy responses. The core of the difficulty has been described by Sunstein:

Regulatory legislation of the 1960s and 1970s has often been indifferent to cost, on the theory that no price tag should be put on life and health, which are "inalienable rights"... No sensible regulatory

See C. Orwin, "Compassion" (1980) 49 American Scholar 309.

I owe this point to Michael Trebilcock.

Supra note 23.

See D. Spulber, Regulation and Markets (Cambridge, Mass: MIT, 1989) Ch. 2.

M. Plattner, "Capitalism" in A. Bloom, ed., Confronting the Constitution (Washington, D.C.: American Enterprise Institute, 1990) 314 at 316. 
program, however, can be indifferent to cost. Regulatory expenditures, if sufficiently high, will endanger the economy, increase unemployment and poverty, and eventually risk both life and health as a result. Programs that seem to be indifferent to cost are in fact influenced by the need for balancing. ${ }^{28}$

Theodore Lowi suggests, along similar lines, "In the (American) liberal regime of the 1960 s, any theory about the cause of injury, if backed by some evidence, was seriously considered a claim to public policy. Consequently, almost everything became good to do. There were no priorities." 29

This last point is of great significance. In fact, command-and-control regulation never did create an absolute right to a pollution-free environment or to a safe workplace. By prohibiting absolutely a select group of hazards or risks while permitting others, legislators and regulators remained faithful in speech to the rhetoric of rights while in practice conducting a concealed and selective set of trade-offs between general economic prosperity under market conditions, and explicit regulatory goals. Hence, while critics of incentive-based regulation and of cost/benefit analysis, such as Steven Kelman, ${ }^{30}$ suggest that these approaches actually break faith with the moral ground of regulation, to some extent this misses the force of the economic critique that the faith has persistently been broken in regulatory practice.

Since no clear overall balancing strategy was being employed, it was easy to show that many of the results of the command-and-control approach were normatively incoherent. For example, many instances could be cited where regulators committed scarce regulatory resources to addressing minor or remote risks, while other risks or hazards of a more serious and certain nature remained unregulated. ${ }^{31}$

\section{INCENTIVE INSTRUMENTS AND ALTERNATIVE MARKET-BASED APPROACHES TO GOAL-SETTING}

Introduction of economic incentives or market-based techniques into regulatory policy purported to address this state of affairs in a number of different ways:

1) By charging a graduated set of fees or taxes for different levels and types of environmental harm, rather than prohibiting some harmful activities while simply permitting others, policymakers could build into the decision-making of regulated entities a principled cost-benefit analysis.

In simple terms, the fine or charge would equal the collectively determined social cost of a given harm. Wherever a firm could either take precautions against the harm at a lower price than the cost of the fine, it would take those precautions and thereby reduce

Supra note 4 at $90-91$.

T. Lowi, "Liberal and Conservative Theories of Regulation" in G. Bryner \& D. Thompson, eds., The Constitution and the Regulation of Society (Provo, Utah: Brigham Young Univ. Press, 1988) at 17. Supra note 15.

See for instance, the discussion of OSHA's carcinogen policy in W.K. Viscusi, Risk by Choice (Cambridge, Mass: Harvard Press, 1983) at 117-118. 
the level of environmental harm. Where, however, the cost of precautions exceeded the fine, a firm would still pollute if its marginal revenue from the pollution-causing activity exceeded the marginal cost of paying the fine. But in that instance, assuming that marginal revenue represents a social benefit, the social benefit from the polluting activity will exceed the cost of curbing it. ${ }^{32}$ Thus, in theory, "the market for final goods will be brought into efficiency and reflect the full social costs of production. Through the operation of the market mechanism, an efficient effluent charge generates efficient emission decisions, efficient output decisions, and efficient decisions on industrial structure. ${ }^{\text {"33 }}$

It is to be noted that this approach is apparently agnostic as to how social benefit is to be measured or determined: the full range of normative arguments relevant to environmental protection - the health of living humans, a respect for the wholeness and purity of the natural horizon in which we live our lives, ${ }^{34}$ our responsibility to future generations - can enter into the calculus of social cost. The fact remains, however, that there is an inherent risk that considerations that are not readily quantifiable, or with which the practitioners of technical cost-benefit analysis are unaccustomed to dealing with, will be given inadequate weight in the policy calculus. As Plattner suggests, "...the reliance of economics on mathematics typically leads economists to ignore or undervalue the significance of nonquantifiable considerations. ${ }^{35}$ This effect may be exacerbated because those who advance the more unquantifiable moral arguments may often bristle at the requirement that they place a dollar value on the chance that life may be saved, or on the purity and harmony of a natural setting. ${ }^{36}$ In fact, most economic methodologies for determining the social cost of pollution focus on a relatively circumscribed group of purported harms. ${ }^{37}$

2) The absence of an obvious technique for balancing different kinds of moral claims relevant to determination of social cost or harm from a given activity, has led some economists to go further, and advocate social cost estimates that themselves are based upon inferences from market behaviour. Thus, for instance, Viscusi has argued that in the occupational health and safety context a valuation can be put on human life by

See Downing, Environmental Economics and Policy (Boston: Little Brown, 1984) at 173-179.

Ibid. at 177-178.

See V. Havel, "The Politics of Conscience" in J. Vladislav, ed., Living in Truth (London: Faber \& Faber, 1988).

M. Plattner, supra note 27 at 333.

Indeed, the argument that economic approaches to law and regulation tend to place a market value on such priceless goods is one of the most frequent objections to this approach. See M.J. Radin. "Market Inalienability" (1987) 100 Harv. L. Rev. 1849 and for a response, M.J. Trebilcock. "Feminism and Economic Analysis of Law" (Paper delivered to Canadian Law and Economics Association Annual Meeting, Toronto, October 1990) [unpublished]. Nevertheless, by no means all social activists see their concerns as unaddressable through market based approaches. Levin and Elman note, for example, that in the United States the Environmental Defense Fund (EDF) has been a strong supporter of market-based approaches to control of acid rain. M. Levin \& B. Elman, "The Case for Environmental Incentives" (1990) Jan/Feb Environmental Forum.

See A. V. Neese, Measuring the Benefits of Clean Air and Water (Washington, D.C.: Brookings, 1984) and J. Haigh, D. Harrison \& A. Nichols, "Benefit-Cost Analysis of Environmental Regulation: Case Studies of Hazardous Air Pollutants" (1984) 8 Harv. Envtl. L. Rev. 395. 
investigating what consumers or workers as individuals are prepared to pay to avoid a given level of risk to life. ${ }^{38}$

There are a number of reasons, however, why these data are an inadequate substitute for collective deliberation about the nature and extent of social cost. First of all, as Sunstein notes, "willingness to pay is a function of ability to pay, and an actor's ability to pay is a function of the amount of goods that have been (legally) allocated to him." ${ }^{19}$ Secondly, workers' choices about risk are influenced by constrained opportunities in the labour market. Perhaps all choices are by definition constrained, but the fact remains that a decision to place a certain value on human life or limb should not be simply determined by such choices without attention to the character and legitimacy of the constraints in question. Indeed, inasmuch as one justification for mandatory occupational health and safety standards is the inequality of bargaining power that persists in many workplaces, it seems contradictory to infer the appropriate level of precautions from preferences that workers have formed historically under these very conditions of inequality of bargaining power.

Rhoads argues that the use of Willingness to Pay (WTP) criteria as means of allocating scarce risk-reducing resources as among different areas of activity must inevitably result in greater focus on saving of older, middle class lives, and away from dangers that affect, for instance, low income earners with large families whose WTP is low since their ability to pay is low. ${ }^{40}$ Another consideration is the social determination of attitudes towards risk - for instance, in a community in which the adult male population has traditionally been employed in coal mining, the high incidence of early death and chronic disease may constitute the given horizon from which risk is viewed." Should this really be seen as a genuine choice for risk?

3) Finally, some policy shifts that have been characterized as incentive - or market-oriented do involve maintaining collective control over the actual level of harm (i.e. the overall emission of pollutants in a given community or by a given firm for instance) but leave, to a greater or lesser extent, to market forces the allocation of resources to achieve this result. Tradeable pollution permits are an example. The total emissions permitted remains a matter for government mandate, but those for whom it costs least to avoid polluting will pollute the least, with those for whom it costs most to pollute using up the permits.

See K. Viscusi, Risk by Choice (Cambridge, Mass: Harvard, 1983). Supra note 4 at 41.

S. Rhoads, "How Much Should We Spend To Save a Life?" in Public Policy Dilemmas (Boulder: Westview, 1980) at 302.

Sec in general, the discussion of adaptive preferences in C.R. Sunstein, "Legal Interference with Private Preferences" (1986) 53 U. Chi. L.R. 1129 at 1146-1147, and J. Elster, Sour Grapes: Studies in the Subversion of Rationality (Cambridge: Cambridge University Press, 1983). 


\section{CHARACTERIZING AND MEASURING SOCIAL COSTS UNDER MARKET-BASED APPROACHES}

The critics of traditional regulation have tended to emphasize the high costs of achieving regulatory goals and have argued that in calculating costs and benefits an expansive view ought to be taken of costs, including not only the "costs" in terms of allocation of capital, labour and raw materials to precautions (for instance, in the environmental area), but also costs of compliance and administration. ${ }^{42}$ There are a number of questions that should be raised about this view of costs.

First of all, it tends to be static based upon an ex ante (pre-regulation) estimate of the costs of the required technology or change in processes. Even though the critics have rightly pointed out that some traditional regulatory approaches - such as BAT (Best Available Technology) - also entrench static notions of costs, ${ }^{43}$ they base their own estimates of costs on existing technology. However, as resources are allocated to research and development to create new processes and technologies, which regulation should encourage, the actual cost of achieving a given level of environmental protection or occupational safety may well go down. Estimates of costs should, therefore, seek to reflect the potential dynamic effects of investment in precautions as a result of regulatory obligations.

Secondly, the critics implicitly view the status quo as an optimal allocation of resources, or as an equilibrium in which private preferences are maximized, but for the specific negative externality which regulation is required to address. However, it is quite possible that regulation will alter behaviour in such a way that additional social benefits, in addition to those associated with the correction of the market failure in question, will accrue. A clear example is the 55-mile-per-hour speed limit set by the U.S. government in 1973 to address the energy crisis. In addition to promoting energy conservation, the limit seemed also to be reducing fatalities on the highways and was thus continued after the original reasons for the regulation were no longer salient. ${ }^{44}$ In the context of measuring the benefits of public supply of adequate health care to the disadvantaged, Lisbeth Schorr notes that many social benefits accrue that are lost sight of in a cost/benefit analysis that confines itself to the health system: "The costs of unattended malnutrition, anemia, child abuse, or lead poisoning do not become incentives to greater prevention or outreach efforts, because these costs do not ultimately fall on the health plan or even the health system. Rather, they show up on the ledgers of the social services, education or corrections systems." 45

See for example, A. Kneese \& C.L. Schultze, Pollution, Prices, and Public Policy (Washington D.C.: Brookings, 1975) at 28: "as environmental objectives become more ambitious, the cost of achieving them rises sharply, in terms of the other aspects of living standards that have to be sacrificed." See the discussion of BAT (Best Alternative Technology) and alternative approaches later in this article.

See M. Friedland, M.J. Trebilcock \& K. Roach, supra note 22 at 41-43.

L. Schorr (with D. Schorr), Within Our Reach: Breaking the Cycle of Disadvantage (New York: Anchor, 1988) at 132. 
Thirdly, with respect to compliance or enforcement costs, where regulation involves agents altering habitual or traditional patterns of behaviour, it may be inappropriate to gauge these costs through analysis of ex ante attitudes of the regulated towards the measure in question.

An example of the ex ante approach is that of regulators at the U.S. National Highway Traffic Safety Administration in the mid-seventies toward the introduction of compulsory airbag requirements in automobiles. The Administrator, James Gregory, accepting the insight of the regulatory reform literature that "many ideas not thoroughly looked at, and thoroughly planned, can be shot down by lack of public acceptance," hearings to gauge public acceptance of the airbag (that resulted in an apparent lack of consensus).$^{47}$ In the case of the interlock device, which prohibited drivers from starting the car ignition if seatbelts were not fastened, poor compliance and public outcry at the program in its first months led to its withdrawal. ${ }^{48}$

In its early stages, however, any regulatory measure that disrupts habitual patterns of behaviour and appears to impose a new constraint on individuals is likely to meet vocal resistance at least from a significant minority. But these compliance costs should not be confused with long term costs. It may take a considerable period of time for government to persuade individuals of the benefit of compliance, and this may include strict enforcement of the law in the short term. Once individuals are induced to alter their behaviour in sufficient numbers, however, the disutility of compliance may become much less. They may discover some actual advantages of the new practice, and their attitude may change in the direction of the attitude that inspired the regulation in the first place. ${ }^{49}$ They may have held false assumptions about the costs and benefits of the new practice (e.g. seat belts are uncomfortable and constraining or seat belts don't really save lives) that may not be corrected in public debate ex ante, but may be corrected as the actual (as opposed to apprehended) results of the regulation become apparent to the individual. Law itself can be persuasive as well as coercive, but sometimes may have to be coercive in order to persuade. Moreover, breaking habits may be costly, ${ }^{50}$ but once new (law abiding) habits are formed, the tendency of individuals to habitual behaviour will make compliance easier and less costly, even as it made compliance more difficult and more expensive at the outset. ${ }^{51}$ On the other hand, laws that rely in the long run on coercion

46. Quoted in J.L. Mashaw \& D.L. Harfst, infra note 56.

47. Ibid. at $460-461$.

48. $\quad$ bid. at 460 .

49. I.e. they may not just obey the letter of the law, but follow its spirit, thereby resulting in surplus social benefits. Friedland, Trebilcock, and Roach suggest: "Perhaps if people can be encouraged to wear seat belts, they might become more safety-conscious generally." Supra note 22 at 39 . See also L. Evans \& R.C. Schwing, eds., Human Behaviour and Traffic Safety (New York: Plenum Press, 1984) at 147.

so. See C.R. Sunstein, supra note 41.

51. On habit and law-abiding conduct, see Aristotle, The Politics, trans. Lord (Chicago: Univ. Chicago Press, 1984) at 72-73. 
largely or exclusively and fail to persuade, are likely to involve very high enforcement costs and/or poor compliance. ${ }^{52}$

\section{E. PROPERTY RIGHTS OR BURDENS OF PUBLIC JUSTIFICATION}

Closely linked to the arguments for the superiority of rules over incentives explored above is the view that the choice of regulatory instrument ultimately reflects a strong social judgment about property rights. Calabresi and Melamed ${ }^{53}$ distinguish between property and liability approaches to legal duty. Society differentiates between wrongs that are prohibited and punished, for which the implicit optimal level of non-compliance is zero, and wrongs for which compensation is considered an adequate vindication of justice, with the corresponding implicit normative judgment that non-compliance is desirable where the social benefit of "wrongdoing" exceeds the price of compliance.

Does a shift from command-and-control to taxes and charges really involve a shift from a property rights regime? As Kelman concedes, under the traditional command-and-control regimes, pollution is not outlawed completely. Under a regime where individuals had a right to be free from pollution, all pollution would be banned, and any exception from the rule would require an explicit collective decision to suspend or abrogate pre-standing property rights. As suggested above, however, a traditional command-and-control regime already presumes that there is a social "price" on environmental regulation, i.e. that the optimal level of environmental protection is determined through a trade-off between the value of such protection and the value of other goods (such as level of employment, economic growth, and technological development) that may be compromised by environmental regulation. A third instrument, subsidies to polluters to induce higher standards of environmental protection, suggests a right to pollute, with society being required to compensate the polluter if it wishes environmental protection.

It is less than evident that the choice for a regime where pollution is generally permitted, unless the right is specifically overridden by prohibition (the traditional command-and-control approach), suggests more stigmatization of environmental harm than a regime where there is a general right to pollute subject to a liability rule to compensate for the harm. A system where environmental harm is totally prohibited subject only to a process where permits are granted in particular cases, seems to reflect a normative perspective that is clearly more stigmatizing of pollution than any of the others. ${ }^{54}$

See for a discussion of these kinds of laws in the context of drug and alcohol regulation C. Mitchell, "Regulative Drug Taxes and Tax Rates: Politics, Efficiency or Justice" (Law and Economics Workshop Paper, University of Toronto, 26 September 1990). More generally, see C. Mitchell, The Drug Solution: Regulating Drugs According to Principles of Justice. Efficiency and Democracy (Ottawa: Carlton University Press, 1990).

s3 G. Calabresi \& A.D. Melamed, "Property Rules, Liability Rules and Inalienability: One View of the Cathedral" (1972) 85 Harv. L. Rev. 1089.

st This approach is reflected for instance in an 1899 U.S. statute that prohibited all discharge of wastes into navigable waterways by industry without a permit issued by the chief of engineers. See A. Kneese \& C.L. Schultze, Pollution, Prices, and Public Policy (Washington, D.C.: Brookings, 1975) at 39 . 
Nevertheless, it is certainly true that some proposals for a shift to incentives implicitly establish burdens of public justification that suggest an acceptance of the view that property rights belong to those undertaking harmful activity. The search for alternatives to command-and-control regulation has been characterized as a search for "least restrictive alternatives," i.e. alternatives least restrictive of what is presumed to be a semi-autonomous zone of private ordering, the "well-functioning competitive marketplace. ${ }^{155}$ It is regulators who must justify their intervention in this sphere, rather than private actors having to bear the initial burden of showing that their activity serves the common good as collectively defined.

In a number of respects, placing the burden of public justification on those who wish to restrict private activity, has itself led to, or exacerbated, certain of the regulatory failures associated with traditional command-and-control regulation.

First of all, regulatory claims may often have been articulated as "rights" in response or reaction to the invocation of property right claims as a justification for non-interference with private outcomes. In the contemporary rhetoric of public justification often only a rights claim can counter another rights claim. Secondly, some of the high information and administrative costs associated with command-and-control regulation can be attributed to the high justificatory burdens placed on regulatory agencies in North America. Requirements that high levels of proof be advanced for the effectiveness of regulatory measures or for the need for regulation have frequently frustrated regulatory efforts and given rise to endless debate between experts, particularly scientists, who take different views of the same data. Absence of strict scientific proof, or the persistence of controversy among the experts has often given vested interests, particularly industry interests, considerable room for manoeuvre in frustrating regulatory initiatives (acid rain is a prime example). ${ }^{56}$

In many areas of government action, such as foreign policy, where it is not presumed that government is "intervening" in an autonomous private sphere, the recognition of limits to deliberation, the incapacity to predict in a scientific manner ex ante the consequences of public action, and the historical record of unforseen results and failed predictions, are not invoked to put in question the legitimacy or necessity of public action or to place extraordinary constraints and burdens on it. ${ }^{57}$

S. Breyer, "Analyzing Regulatory Failure: Mismatches, Less Restrictive Alternatives, and Reform" (1979) 92 Harvard Law Review 549 at 550.

56 See also J.L. Mashaw \& D.L. Harfst's dramatic account of how judicial review of statutorily imposed demands for justification of regulatory measures "burdened, dislocated, and ultimately paralysed" the rule-making activity of the U.S. National Highway Traffic Safety Administration. "Inside the National Highway Traffic Safety Administration: Legal Determinants of Bureaucratic Organization and Performance" (1990) 57 U. Chi. L.R. 443 at 443.

57 Some regulatory reform advocates, such as Stephen Breyer, suggest that placing a high justificatory burden on the intervener, does not itself imply a certain hierarchy of public values, or involve striking a balance between public values in a particular way. Breyer asserts: "Because the assumption that an unregulated marketplace is the norm does not rest on the adoption of a particular set of values, the analysis should point to conclusions and proposals which would be accepted by persons holding a broad range of political values and beliefs." Supra note 55 at 552 . Breyer neglects the fact that it took 


\section{F. REDISTRIBUTIVE CONSIDERATIONS AND THE SHIFT TO INCENTIVES}

A significant aspect of the logic of shifting to incentive-oriented instruments is the capacity to vindicate certain distributive justice goals while avoiding intrusive interference with private social and economic arrangements and market allocation decisions. Those who take the "incentives" side in the "rules vs. incentives" debate have, however, a tendency to mischaracterize the real ethical goals of the old instruments as redistributive. For instance, to point out that rent controls are a self-defeating method of subsidizing the poor is to admit only part of the story. Rent controls may also serve other goals such as the preservation of mixed neighbourhoods, or the provision of some security against sudden rent increases that may force a family to leave its home. Providing vouchers or subsidies as a substitute instrument may not serve properly these other goals. Landlord and tenant regulations that relate to habitability of the premises, also characterized by some regulation critics as bad attempts at subsidization, ${ }^{58}$ may reflect a social judgment about the moral imperative not to transfer wealth to the disadvantaged, but to protect them from certain kinds of reprehensible exploitation in individual transactions or bargains. This might also be the case with minimum wage laws, where we make a collective moral judgment that full-time employment of adults at compensation that generally does not allow for a humanly decent life constitutes exploitation of the necessitous and weak by the strong, and is somehow closer to slavery than to free exchange.

The point here is not whether this judgment is right or wrong, but that it is not, at its core, a judgment about redistribution. Therefore, the argument that the same normative goals can be vindicated through straightforward tax and transfer instruments becomes quite suspect. As Plattner notes, "this is an error to which economists are particularly prone, given their penchant for focusing on economic effects (i.e. how much is being transferred to whom) rather than political principles (i.e. on what grounds the money is being transferred). ${ }^{n 9}$ Although as Plattner also suggests, the reformulation of the aims of social regulation as redistributive owes as much to the difference principle of liberal

a revolution in values in the $16 \mathrm{th}$ and 17 th centuries, for anyone to be able to look at the unregulated marketplace as the norm. Prior to this revolution, wide-ranging constraint on market activity was the norm, and the justificatory burden was squarely on the shoulders of those seeking liberalization of commerce. See S. Chodak, The New State: Etatization of Western Societies (London: Rienner, 1989) ch. 10. Breyer equally ignores the continuing weight and importance of the critique of the view that unregulated markets are the norm, even in societies that have come to reject the revolutionary call to replace exchange with command, and to abolish private ownership. See A. Bloom, "Rousseau: The Turning Point" in Confronting the Constitution (Washington D.C.: A.E.I.. 1990) elaborating the consequence of what he describes as Rousseau's "delegitimization of property's emancipation from political control" at 223-224. See C.R. Sunstein, supra note 2.

M. Plattner, "The Welfare State vs. The Redistributive State" (1979) 28 The Public Interest at 48. The observations that follow owe much to this seminal article. 
political philosopher John Rawls as to any conservative economist, redistributive arguments have been invoked to justify a retrenchment of the welfare state. ${ }^{60}$

Hence, minimum wage laws have been criticized on the grounds that they create unemployment among the most vulnerable and disadvantaged of .workers. ${ }^{61}$ The argument, as paraphrased by Sunstein, is that "if everything else is held constant, the market will frequently adjust to the imposition of regulation in a way that will harm the least well-off." ${ }^{62}$ But why (as Sunstein notes) hold everything constant? The minimum wage may be understood as part of a general social vision of work with dignity that involves comprehensive unemployment insurance and reskilling for workers whose existing marketable skills do not "justify," on productivity grounds, the minimum wage. Indeed, labour shedding may not be the only private response to high labour costs posed by the minimum wage. Based upon studies of the effects of various forms of regulation protective of workers in West Germany and Sweden that impose higher costs on employers, Streek concludes that these "contributed to raising employer investment in training and retraining above the level of other countries. ${ }^{163}$

Redistributive arguments are often used as well, to criticize government programs that appear to benefit disproportionately, the well-off, such as provision of higher education as a public good, or support for the arts. ${ }^{64}$ Given the background inequalities that persist in our society, these public goods are much more likely to be used by the well-off than by the poor.

This kind of argument is potentially misleading - for even if (given social structures and inequalities as they are) fewer of the disadvantaged benefit than the more advantaged, without government involvement almost none of the disadvantaged would have any access to the good in question. Policies that appear to disproportionately benefit the better off may still confer some net benefit to the least advantaged, and if so they would be broadly consistent with Rawls' difference principle.

It is often claimed by economists that the better way of providing the benefit to the less advantaged is a direct subsidy or voucher that allows them to buy it on the marketplace. But, of course, this reply presumes that public provision in the first place was a badly targeted redistributive policy, and not undertaken for reasons quite other than redistributive (for instance, recognition that education and the arts provide public goods for which many

Ibid. at 34-40. I have summarized elsewhere the difference principle in the following way: "...behind the veil of ignorance where the social contract is constructed and where our individual lots in life and endowments are not known, we would all agree that no collective policy should be pursued that does not improve the lot of the least advantaged. In other words, we would all agree to a form of social insurance against the risk of finding ourselves in this plight." M.J. Trebilcock, R. Chandler, \& R. Howse, Trade and Transitions: A Comparative Analysis of Adjustment Policies (London: Routledge, 1990).

6. See F. Welsh, Minimum Wage: Issues and Evidence (Washington, D.C.: AEI, 1978) at 422.

62. Supra note 2 at 422.

63. W. Streek, "Comment on Ronald Dore, 'Rigidities in the Labour Market'" (1990) 23 Government and Opposition 413 at 420.

6. M. Plattner, supra note 59. 
individuals as citizens are willing to pay more than as individual consumers). ${ }^{65}$ Moreover, in the case of support for the arts, government seeks not only to benefit the consumers of artistic production but also the participants, giving them an opportunity to develop distinctive human excellences that might go undeveloped or underdeveloped if public support were absent.

The appropriate conclusion in such cases is not that government action is in violation of distributive justice, but that there is a further requirement to address those background inequalities that lead to the better-off being able to benefit disproportionately from the public programs in question. A society that commits itself to provision of education as a public good should as a matter of distributive justice also commit itself to measures that permit the less well-off to take full advantage of that good.

The economist's focus on redistributive effects of policies is salutary, inasmuch as it permits identification of purely or largely rent-conferring policies that serve client interest groups while being masked behind the rhetoric of public interest. In other cases, where policies are in fact motivated by legitimate public values other than those of redistribution, knowledge of these effects may suggest the need for additional policies to address distributive justice. But rarely will the case be clear that the regulatory state should retrench, either by eliminating the policies or replacing them by purely redistributive measures such as direct transfers that are purportedly less disruptive of markets.

\section{G. CONCLUSION}

Both the advocates and critics of regulatory reform have tended to oversimplify or misjudge the complex normative considerations at issue in choosing among different kinds of approaches to the regulation of social harms. In some contexts, the use of incentive-oriented instruments is compatible with a high degree of collective control over the determination of what amount and what kind of harm is acceptable. On the other hand, in other contexts, shifting to incentives does mean accepting the consequences of leaving to market forces some important normative trade-offs. And furthermore, some of the ethical salience of command-and-control instruments may be sacrificed by their replacement with other more market-friendly instruments such as direct subsidies or grants. The normative dimension cannot be captured by any kind of simple contrast between the purported ethical properties of incentive instruments in general, as against those of command-and-control instruments in general.

In some contexts the coherence of economic-oriented or market-based techniques for weighing the costs and benefits of policies is largely illusory. These approaches reduce competing and diverse claims to a common metric, but at the cost of oversimplifying and often distorting the moral basis of the claims in question, or of dismissing or marginalizing some of these claims. 
The failure of traditional regulatory processes to provide a coherent basis for making trade-offs among conflicting goals requires a different kind of response, which acknowledges both the irreducible diversity of human goods ${ }^{66}$ and the necessity in political and regulatory practice of ordering and choosing among these goods.

As a preliminary step in determining this response, it is necessary to explore how conflicting or apparently conflicting norms can be specified explicitly ${ }^{67}$ and discussed openly within the regulatory process; how qualitative concerns can be appropriately reflected in the formulation of regulatory responses; ${ }^{68}$ and how a language of public justification can be evolved that neither simply relativizes normative goals as preferences to be aggregated nor absolutizes them as rights or proprietary entitlements. ${ }^{69}$

\section{DILEMMAS, PARADOXES, AND COMPLEXITIES IN THE DESIGN AND IMPLEMENTATION OF INCENTIVE INSTRUMENTS}

In this section, I focus on a different set of problems that may emerge from too literal adherence to the stylized and dramatically contrasting characterizations of "command-and-control" and incentive instruments discussed in Part I. The tendency to view the latter instruments as relatively automatic, self-enforcing, and non-intrusive, may well lead to an underestimation of the difficulty of designing good incentive instruments. Some of the same misassumptions and design errors that can cause command-and-control instruments to fail, menace incentive-oriented instrument choices as well.

\section{A. COMPLIANCE COSTS AS AGENCY COSTS}

The logic behind the shift from command-and-control to incentive instruments is at one and the same time informed by a belief in the capacity of the latter to provide better targeting of government intervention to the specific, often redistributive goals at issue, i.e. the capacity to achieve these goals without incurring the costs involved by taking a more

See C. Taylor, "The Diversity of Human Goods" in Philosophy and the Human Sciences: Philosophical Papers, vol. 2 (Cambridge: Cambridge University Press, 1985).

On the specification and explicit justification of norms as a precondition to the resolution of normative conflicts in practical contexts, see H.S. Richardson, "Specifying Norms as a Way to Resolve Concrete Ethical Problems" (1990) 19 Philosophy and Public Affairs 302.

Martha Nussbaum argues that social policy, for example, can be informed by an understanding of human needs and functioning that involves "a rich variety of qualitative distinctions." "The idea is to ask how people are doing, by asking how well their form of life has enabled them to function in a variety of distinct areas, including but not limited to, mobility, health, education, political participation, social relations. This approach refuses to come up with a single number, reducing quality to quantity.... Nonetheless, the approach does actually permit modelling and measurement." M.C. Nussbaum, "The Literary Imagination in Public Life" (Legal Theory Workshop, Faculty of Law, University of Toronto, 8 February 1991) at 31.

See M. Ignatieff, The Needs of Strangers (New York: Viking, 1985) at 141-142: "We . . need, as much as anything else, language adequate to the times we live in.... Our needs are made of words; they come to us in speech, and they can die for lack of expression. Without a public language to help us find our own words, our needs will dry up in silence." On the concept of justification of policy choices, and the institutional issues it raises, see S. Macedo, "The Politics of Justification" (1990) 18 Political Theory. 
cumbersome route, and also by a preference for decentralization, greater dependence on private actors, etc. These concerns will often be in tension, however, in choosing among incentive instruments.

Absent complete public provision (with the consequence of bureaucratic expansion and a high degree of centralization, identified with undesirable features of command-andcontrol instruments), targeting requires the use of various devices to cope with the fact that the private actors involved in delivery may have interests that do not coincide with those of the government. These devices may entail costs as high as the monitoring and enforcement costs that were considered to be among the major drawbacks of command-and-control regulation. ${ }^{70}$

Some examples are in order. Government may want to use trade restrictions to allow an industry breathing space to modernize and restructure: managers and owners of firms may be better off taking the rents from trade restrictions and using them to invest in other sectors, an objective obviously in tension with the government's desire to sustain long term employment in a given industry or firm. ${ }^{71}$ More targeted policies, however, would likely require detailed contracts or understandings between government and firms, potentially more intrusive and more dependent upon bureaucratic control or monitoring of firm behaviour.

In the case of the "bubble" scheme for tradeable pollution permits, Hahn and Hester suggest that the cost of preparing and planning bubble applications has deterred firms from taking advantage of the incentives provided, except where very large cost savings are involved. ${ }^{72}$

A decision to shift from command-and-control regulation to incentive-based instruments converts the problem of the costs of coercion (recognition of these costs may be an important motivation behind the shift) into an agency costs problem. The dilemma in question will be familiar to students of corporate finance. ${ }^{73}$ It is neatly summarized by Ziegel et al.:

At the core of the analysis undertaken by (agency) theorists is the conception of the corporation as a nexus of contractual relationships among the corporation's shareholders, creditors, managers, employees, and suppliers. Although this delegation allows for specialization of tasks, it entails the danger that the delegates (the agents) will use their delegated authority to pursue their own goals at the expense of those goals favoured by the delegators (the principals). ${ }^{74}$

See Donahue, The Privatization Decision: Public Ends, Private Means (New York: Basic Books, 1988).

M.J. Trebilcock, R. Chandler, \& R. Howse, supra note 60 at c. I.

G.L. Hester and R.W. Hahn, infra note 89. See also R.W. Hahn, "Economic Prescriptions for Environmental Problems: Not Exactly What the Doctor Ordered" in J. Shogren, ed., The Political Economy of Government Regulation (Boston: Kluwer, 1988) at 180. concluding, on the basis of a survey of experience with a range of incentive-based instruments that "economic approaches to environmental reform are much more complicated than had initially been theorized."

Supra note 18.

Ibid. at 369. 
There is a different set of monitoring and compliance problems associated with delegation to economically self-interested agents, but they are potentially no less difficult. The more flexibility and scope that incentive-oriented instruments provide to the agents and hence the more that they tend (in Sunstein's words) to "embody the flexibility, adaptability, productive potential, and decentralization characteristic of private markets, ${ }^{\text {"75 }}$ the more scope the agents may also have to pursue objectives of their own that are in tension with, or that defeat public goals.

For example, with respect to subsidization of private firms to provide on-the-job training, the interests of employers may conflict with those of the government. The government will want to see beneficiaries trained in skills that are portable in the economy, and individuals selected for the program who would otherwise remain unemployable. But, as Donahue suggests:

The employer is better off training workers in strictly firm-specific skills. The employer is also better off accepting wage or screening subsidies (packaged as on the job training subsidies) without departing from normal hiring patterns. ${ }^{76}$

Lund describes difficulties with government use of private financial institutions to deliver loans or loan guarantees to small businesses and to students. An apparent advantage of this delivery mechanism is that "[it] reduce[s] government processing time and administrative costs by tapping lenders' expert knowledge about potential borrowers."77 Nevertheless, because government assumes the risk of the borrowing, the institutions are likely to take less care in their credit assessment and collection activities than in those instances where the institutions' own capital is at risk.

In both these examples, the conflict of interest could be controlled by detailed contracts and extensive monitoring of private actor behaviour by government, but this would entail precisely the kind of administrative costs and control that reliance on private actors was intended to avoid.

A recognition of the agency cost problem need not lead to a sense of defeatism about shifting to reliance on private, economically self-interested decisionmakers. What may be required is a new approach to monitoring and a compliance that itself places greater reliance on incentives in addressing the agency problem. Control and monitoring have often been identified as core governmental functions (although using independent consulting firms to evaluate programs appears to be increasingly commonplace). Government may, however, be able to delegate some key monitoring functions to actors who have an interest in the compliance of other private actors with public goals.

Often, government programs have beneficiaries that have an interest in compliance of delivery agents with government purposes. For instance, to return to the industrial subsidy

M. Lund, "Between Welfare and the Market: Loan Guarantees as a Policy Tool" in L. Salamon, ed., Beyond Privatization: The Tools of Government Action (Washington, D.C.: Urban Inst., 1989) at 146. 
example mentioned earlier, the subsidy is provided to the firm, but workers may be targeted as the real beneficiaries. Government might condition the provision of subsidies premised on long-term job creation on an active role for workers themselves in monitoring the firm's use of subsidies, and require that the firm disclose detailed information to workers about medium and long-range corporate strategy.

In the occupational health and safety area, providing workers with real clout and capacity to monitor and enforce standards may be a superior alternative to the choice between market incentives addressed to managers and shareholders (experience rated premiums) or costly and often ineffective monitoring and enforcement by government bureaucrats. ${ }^{78}$ Giving workers the information necessary to assess employer and fellow-employee compliance with regulations, as well as with legal protections against employer retaliation may be appropriate policy measures, where the workplace is unionized. A statutorily entrenched right to refuse unsafe work, a plank in the policy platform of the Ontario NDP government, could be a powerful weapon in the monitoring and enforcement of occupational health and safety standards. Worker behaviour itself will signal non-compliance with standards and also may reveal new risks that may require appropriate regulatory attention. And in this last respect, the issue is not just compliance. It is also one of a voice for workers themselves, the most direct beneficiaries of health and safety policy, in the definition of appropriate standards and practices. Giving workers a direct voice seems normatively superior both to traditional bureaucratic determination of appropriate standards, practices, and levels -- indifferent to workers' own risk perceptions and preferences and to determinations that rely on market-based criteria that (as argued in Part II) abstract from the moral significance of the constraints under which workers express preferences about risk through market behaviour.

\section{B. CONFLICTING INTERESTS AND INCENTIVES WITHIN REGULATED ENTITIES}

This last example evokes the significance of conflicting interests or incentives within a given institution, another key insight of agency theory. Shifting to incentives means recognizing that firm behaviour is not determined by automatic reaction of market signals, but often to a significant extent by the way that incentives are skewed among the diverse stakeholders in the firm. Again the lesson is that the apparent simplicity to be gained from moving away from command-and-control towards reliance on incentives is quite deceptive in many contexts.

The need to go beyond analysis of the incentives that drive firms to an examination of the incentives that drive their diverse constituencies and stakeholders is illustrated by the example of pollution charges as a substitute for mandating Best Available Technology (BAT).

The argument tends to assume that firms will be indifferent between spending a given amount on a precaution and paying a charge. Therefore, it is assumed, a charge will 
maximize cost-efficient investment in new technology. As long as the investment amortized over a given period of time is less costly than paying the charge, firms will make the investment.

However, there are reasons to doubt that this will be the case. Managers may feel their performance is judged on short-term balance sheet results, and may be disinclined to commit significant resources to development of new technologies that have the potential to produce future cost-efficient reductions in emissions, if this involves high expense and indebtedness in the short term. Hence, they may simply pay the charge even when it is cost-efficient to innovate.

\section{SELF-DEFEATING OR PERVERSE INCENTIVE ASPECTS OF INCENTIVE INSTRUMENTS}

A shift away from command-and-control instruments, in part motivated by a recognition that they have resulted in self-defeating regulatory strategies or created perverse incentives (i.e. perverse in respect to the public goals at issue), should not lead to the assumption that such ill effects are unlikely to be duplicated in the design of incentive instruments themselves.

Here, again, the example of supposedly incentive-oriented environmental protection instruments, (such as charges and transferable permits) is relevant. Under a charge system, firms face a choice between investing in precautions and paying a certain fee. Even if it may be cheaper for all firms to adopt a certain precaution than pay a given fee, free rider and collective action problems may lead each firm to choose the fee. None of them may want to be the first to invest in research and development of a precaution, much of the benefit of which will eventually be conferred on other firms as well.

In the area of environmental regulation in particular, reform advocates such as Stewart and Ackerman have argued that a major advantage of tradeable permits for pollution is that they create incentives for technological innovation. A firm has an incentive to find ways of reducing the cost of pollution control so that it can sell the rights to pollute to other firms whose costs of control are higher. ${ }^{79}$ Sunstein suggests that:

...a fundamental virtue of an emissions trading program is that it would create dynamic incentives for pollution control by making it profitable for people to develop good pollution control technology. Those who developed such devices would be able both to reduce their own pollution and to sell the technology to others. ${ }^{80}$

But there is a paradox here. If the incentive to develop the technology is to be able to sell the permit to a firm that has a higher cost of pollution control, then the tradeable permit approach is inherently self-defeating, for once the technology is available, why would the other firms want to purchase the permits? If anything, the tradeable permit approach 
would seem to provide an incentive to develop control technologies that are not easily transferable to other firms and industries, since to make a "profit" from selling a permit, a firm must innovate in such a way that it remains more expensive for other firms to acquire the innovation than the permit.

\section{THE DANGERS OF OVER-RELIANCE UPON AXIOMATIC ASSUMPTIONS ABOUT ECONOMIC SELF-INTEREST}

Many advocates of incentive-oriented policy reforms appear to regard regulators as being in principle capable of making good predictions about behaviour on the basis of assumptions that individuals act in their economic self-interest. Schultze's contrast between the inherent weakness and unreliability of altruism and moral duty as motivators of human conduct, and the reliability of self-interest is a particularly striking instance of this kind of reasoning. ${ }^{81}$

In fact, reliance upon axioms about self-interest that presuppose a model of economic rationality for human conduct may lead to misdesign of incentive instruments. Much of the literature that examines the incentive effects of legal rules relies heavily on general assumptions about self-interested behaviour to explain the empirical evidence of regulatory failure. These axioms may be deficient in a number of respects. I wish to explore several examples from the area of welfare reform.

1) Measures designed to provide an incentive to work for welfare recipients through offering them both a top-up of low employment wages are premised upon the assumption that what is needed is to make work significantly more financially attractive than welfare. ${ }^{82}$ However, if welfare recipients choose welfare over work, not only because of a lack of differential in financial rewards, but because the work available to them offers few incremental rewards in terms of personal self-development or self-esteem, financial incentives alone may not make the crucial difference. Such incentives may have to be supplemented by programs for upgrading of skills, or other measures that succeed in giving welfare recipients the alternative of employment that is not only financially but also humanly rewarding. Defining the goal as simply getting people off of assistance, or pushing them from the welfare rolls to the lowest rungs in the workforce, is much too narrow.

2) A further problem not captured by a narrow focus on economic self-interest may be that of recipients' beliefs about their own capacities. The longer one is on assistance, the more likely one will be to assume that more attractive alternatives are not within one's grasp. Providing opportunities and incentives through new spending programs may have little effect if a large part of the underlying problem is these adaptive preferences. Government may need, as well, to support self-help groups and other structures aimed at

82 See for example Ontario Ministry of Community \& Social Services, Work Incentives and Disincentives in Ontario (Report of the Ontario Social Assistance Review Committee) by E. Lightman (Toronto: Queen's Printer, Feb. 1987). 
the development of self-confidence and the education of recipients about their own capacities.

3) Assumptions that behaviour is motivated by desire for financial gain may result in an expensive misdirection of enforcement and compliance efforts. For instance, welfare recipients' non-reporting of income or other changed circumstances may be something quite other than a calculated fraud. Reporting requirements may be confusing, onerous or humiliating. Simplification of these requirements may be a superior alternative to increasing the costs of cheating to recipients, through monitoring and enforcement with fines and other penalties.

\section{COMMAND-AND-CONTROL REVISITED}

In this section, I explore some examples of opportunities for better government that involve changes within command-and-control instruments or the development of new instruments of this type. Some of these opportunities risk being overlooked or underestimated through an exclusive focus on "incentive-oriented" policy shifts.

\section{A. INTRODUCING FLEXIBILITY INTO COMMAND-AND-CONTROL APPROACHES}

In "Smaller or Smarter Government?," some associates and I suggested that a recognition of the complex compliance and enforcement problems with command-andcontrol instruments ${ }^{83}$ was among the most salient lessons of the incentive-oriented shift in instrument choice. Advocates of incentive-oriented regulatory reform frequently contrast the multiple bureaucratic demands of monitoring and enforcement of rules with the relative automaticity of incentive-based instruments. Some of the claims in this respect for these latter instruments are derived from a detailed examination of instrument choice in specific areas of regulation, such as pollution controls, where a change in the mix between rules and incentives was claimed to reduce certain monitoring and information costs. ${ }^{84}$ Stewart emphasizes that with command-and-control regulation, "decisional and compliance outlays also include diversion of management and research resources to regulatory matters, a diversion that may involve substantial opportunity costs. ${ }^{185}$ While the change of regulatory approach recommended by Stewart in the environmental area would quite arguably reduce compliance and enforcement costs by replacing detailed rules and standards by general expectations for a certain level of environmental performance, the overall characterization of this shift as a shift from rules to incentives may be inaccurate. The added flexibility of a system that mandates overall levels of pollution reduction rather than compliance with detailed rules need not hinge on replacement of incentives for compliance with punishment for non-compliance.

R. Howse et al., supra note I at 524-525.

See B.A. Ackerman \& R.B. Stewart,"Reforming Environmental Law: The Democratic Case for Market Incentives" (1988) 13 Columbia Journal of Environmental Law 171; R.B. Stewart, supra note 7.

R.B. Stewart, ibid. 
For instance, under a command-and-control system regulators could move to mandate a general level of performance from individual firms based upon a plausible assessment of the fair burden for environmental protection they should bear. Firms could be required to propose to regulators a cost-efficient package of proposals. Ayres and Braithwaite note that "the U.S. Mine Safety and Health Administration regulations ...permit mine operators to submit their own plans, for ventilation, dust control, and roof support for the agency's approval. ${ }^{.86}$ Cohen notes, for example, that with respect to environmental regulation in Canada there is a trend to "more sophisticated incremental (albeit command) models of regulation which link a range of penalties to increasingly harmful activities." ${ }^{187}$

A similar logic underlies the U.S. OSHA's Cooperative Compliance Program, where firms with an overall superior safety record are given significant scope to monitor and enforce internally OSHA's mandated (i.e. "command-and-control" style) standards. As Rees argues, this program represented a notable departure from "emphasis on highly centralized and rule-bound methods of social control. ${ }^{88}$ As Hahn and Hester describe it, the U.S. Environmental Protection Agency's bubble program allows "a firm to increase emissions at one or more emission sources in exchange for larger decreases at other emission sources so that the total emissions from a facility do not exceed the sum of all the sources' individual emission limits. ${ }^{189}$ While Hahn and Hester themselves describe this as a "market-based pollution control system," 90 it is very far removed from the "pay to pollute" characterization of the instrument shift in environmental regulation regulatory fiat, not what firms are prepared to pay to pollute, still determines the level of emissions permitted. The new system merely makes allowance for the relative cost within a given firm of reducing emissions by a given amount from each source. And again, this could be achieved by negotiation of a tailored emission-reduction scheme between regulators and the firm.

\section{B. REPLACING OLD COMMAND-AND-CONTROL INSTRUMENTS WITH BETTER-TARGETED OR FINER TUNED INSTRUMENTS}

Among the most cited examples of the economic and social justice case for moving from a command-and-control regime to directly redistributive policies is rent controls. ${ }^{91}$ However, the economically optimal policy of providing subsidies to low-income renters may be politically unfeasible due to lack of budgetary resources with which to provide the subsidies, and also due to the fact that the program gains political weight from the

I. Ayres \& J. Braithwaite, Responsive Regulation: Transcending the Deregulation Debate, (American Bar Association and Research School of Social Sciences, Australian National University, 1990) [unpublished] at 170.

D. Cohen, "Procedural Fairness and Incentive Programs: Reflections on the Environmental Choice Program" in this volume.

J.V. Recs, Reforming the Workplace: A Study in the Self-Regulation of Occupational Health and Safety (Philadelphia: U. Penn Press, 1988) at 15.

"Where Did All the Markets Go? An Analysis of EPA's Emissions Trading Program" (1989) 6 Yale Journal on Regulation 109 at 123.

Ibid. at 110.

See for example, W.Z. Hirsch, "From 'Food for Thought' to 'Empirical Evidence' About Consequences of Landlord-Tenant Laws" (1984) 69 Cornell Law Rev. 604. 
ethically perverse consequence that it benefits middle-class voters. In addition, as discussed above (III.F.), non-redistributive goals of rent control may not be served. One alternative to subsidies might be a tax on speculation in the land and housing market, if it is the case that part of the reason for high (and rapidly increasing) rents is "overheating" created by speculation. Since among the reasons that rent controls benefit a wide constituency is that they provide some insurance against large unpredictable rent increases that may force a family to move out of its home, ${ }^{92}$ it might be possible to substitute actual statutory control of the amount of rent increases with a provision that landlords be required to make a legally binding commitment in advance to tenants as to the maximum increases in rent over a significant period of time (say, 3-5 years). In effect, landlords would be obliged to estimate in advance the increases needed to reflect increased maintenance and other relevant costs, and be required to bear the risk of these estimates being inaccurate. But the estimates themselves would reflect market forces. Tenants would be afforded a measure of the security that is enjoyed by homeowners, who know (assuming that their property is not mortgaged with floating-rate or very short term mortgages) that the occupancy of their home will not be threatened by short-term economic vicissitudes.

One instance where regulatory reform has been accompanied by new command-and-control measures is telecommunications deregulation in the United States. Contrary to the optimal approach suggested by the theorists of the incentive-oriented shift, low cost service to residential users is ensured by many state governments under conditions of demonopolization and rate competition, not by subsidies to low-income users but by mandating price ceilings on residential service. Although this arguably still distorts markets more than subsidies, it clearly still permits many of the gains of competition to be captured, i.e. in all products but basic residential service, while addressing the normative concerns implicit in the old command-and-control system. ${ }^{93}$

\section{INCENTIVE INSTRUMENTS THAT WORK BEST IN CONJUNCTION WITH NEW COMMAND-AND-CONTROL INSTRUMENTS}

In other work, I have made the argument that adjustment assistance is usually a far superior instrument for dealing with the consequences of employment dislocation due to trade impacts than trade barriers or production subsidies. ${ }^{94}$ However, adjustment assistance (retraining, job search assistance, income support during job search), as empirical evidence suggests, is most effective in achieving successful adjustment when workers have advanced notice of job loss and are able to begin the search and adjustment process while still employed. There are a number of reasons why this may be true: workers may be more self-assured in looking for alternative employment while still

93. See A. Kahn, "Regulation in the 1990s" (1990) 7 Yale Journal on Regulation 325 at 336-337, arguing "that they (rate freezes for basic telephone service) provide direct, straightforward protection for consumers of the services that are the subject of most intense regulatory concern" without the efficiency distortions created by traditional rate-of-return regulation.

4. The evidence is reproduced in detail in R. Howse, Economic Case for Plant Closing Laws (Faculty of Law, University of Toronto, 1989) [unpublished]. 
employed; the workplace structure can provide the foundation for mutual support groups among employees and their families; the psychological stress of losing the structure of worklife, and of a totally altered personal routine diverts energy and attention from the search process. ${ }^{95}$

To be effective, therefore, a shift from trade restrictions or production subsidies to labour adjustment assistance may have to be accompanied by statutorily mandated notice periods for plant shutdowns and large-scale lay-offs. The rhetorical thrust of the regulatory reform movement would be against such restrictions, seen, in contrast to the largely redistributive measure of adjustment assistance, as distortive of resource allocation by firms. Yet a new command-and-control instrument tailored to work with a targeted spending instrument may be both less distortive overall of allocative efficiency and more successful in vindicating the public values at issue than the old command-and-control and old spending instruments (trade restrictions and production subsidies respectively).

\section{ECONOMIC INCENTIVES AND LIMITS AND POSSIBILITIES OF SOCIAL TRANSFORMATION}

\section{A. GOVERNMENT, MARKETS, AND SOCIAL CHANGE}

Even if one views careful application of incentive-oriented policies as likely to lead to smarter rather than smaller government, and believes as argued above that command-andcontrol instruments can themselves be adapted to respond to the critique of traditional regulatory approaches, it is possible, at the same time to see the shift to incentives as a manifestation of the limits of the regulatory state, and a repudiation of its capacity for broad social transformation, or of its tractability to utopian concerns. The lesson seems to be that the regulatory state can only achieve such protection of workers, preservation of the natural environment, alleviation of poverty, etc. as is consistent with the existing institutions and practices of capitalism. ${ }^{96}$

To many, this will seem a blessing. Inasmuch as broad social transformation in the service of utopian ideals involved the abolition of private property and the collectivization of investment and consumption decisions, (as it was understood by the Marxist tradition to entail) utopianism might rightly be identified as among the greatest political failures of the 20th century.

See, in general, P. Kelvin \& J. Jarrell, Unemployment: Its Social Psychological Effects (New York: Cambridge Univ. Press, 1985). Consider the family stresses that can emerge when a family member accustomed to working outside of the home everyday suddenly finds herself unoccupied at home. observed by Tocqueville in the aftermath of the French Revolution: "La generation qui voit finir une grande revolution est toujours inquiete, mécontente et triste." (A. de Tocqueville, "Discours de M. De Tocqueville prononcé dans la seance publique du 21 avril 1842," in A. Jardin, ed., Tocqueville: Oeuvres (I) (Paris: Gallimard, 1991) 1199 at 1201. 
Over the last couple of decades, however, the capacity of the liberal democratic, social welfare state to tolerate and facilitate profound social change has indeed been remarkable. This confounds in some sense the analysis of both the Right and the Left about the ultimate consequences of "The Sixties."

Drawing on the Weberian notion that capitalism depended for its early success on an ascetic morality emphasizing the value of work and the virtue of postponement of gratification, neo-conservatives such as Daniel Bell ${ }^{97}$ and Irving Kristol, ${ }^{98}$ have viewed the challenge of sixties radicals to traditional values of work and family as a danger to liberal political economy.

The Left has tended to identify radical or fundamental social change with a revolutionary moment in which the basic institutions and practices of society are overturned with great rapidity and decisiveness. ${ }^{99}$ In recent legal and political theory, Roberto Unger has contrasted "context-smashing" (putting the basic terms of social life in question) with pessimistic liberal politics that merely puts the best face on an intolerable and unjust status quo. ${ }^{100}$ From this perspective, the sixties represent the lost revolution, and the subsequent reaffirmation of liberal institutions is a symptom of disillusionment.

In fact, however, both these readings of recent history are defective. The multiplication of alternative lifestyles, ${ }^{101}$ the liberalization of sexual morality, the challenge to the promethean view of nature as something to be conquered for the sake of endless economic growth, the increasingly open and direct response to the previously hidden or denied atrocity of child abuse - all these challenges to traditional norms, taboos, and behaviour have at least begun to make a significant impact on social attitudes and practices within and through the liberal democratic social welfare state. The progressive social agenda seems more consistent with the basic political and economic institutions of liberal democracy than either the Right or Left would tend to admit. ${ }^{102}$

D. Bell, The Cultural Contradictions of Capitalism (New York: Basic Books, 1975).

I. Kristol, Two Cheers for Capitalism (New York: Basic Books, 1978).

For the roots of this approach in modern political theory, see B. Yack, The Longing for Total Revolution (Princeton, N.J.: Princeton U. Press, 1986).

See R. Unger, False Necessity (Cambridge: Cambridge U. Press, 1987).

See the analysis of the case of West Germany by W. Zapf, "L'Allemagne exemplaire" in D. Schnapper \& H. Mendras, ed., Six manieres d'etre europeen (Paris: Gallimard, 1990) 121. Zapf identifies "une pluralisation des modes de vie" at 134 as among the most prominent features of the social evolution of the contemporary social welfare state. See also W. Zapf, "Innovationschancen der westeuropaischen Gesellschaften" (The Possibilities for Innovation in Western European Societies) Soziale Welt, Sonderband 4, 1986, at 167-179.

See, in the American context, N. Tarcov, "The Social Vision of the Founders," in A. Bloom, ed., Confronting the Constitution, supra note 27 at 167. Tarcov argues that the political and legal institutions embodied in the American constitution are capable of accommodating and even nourishing a variety of different social visions. He notes, in implicit response to neo-conservatives such as R. Bork, The Tempting of America: The Political Seduction of the Law (New York: Free Press, 1990) that the founders themselves did not agree on a vision of society, despite their agreement about the structure of the constitution. 
Common to the equally harsh judgments on the liberal democratic, social welfare state by both the Left and the Right has been an implicit expectation of rapid if not immediate results. ${ }^{103}$ One of the main thrusts of the conservative regulatory reform literature is that social policies developed in the $60 \mathrm{~s}$ and $70 \mathrm{~s}$ simply produced disappointing results as against avowed expectations. From this gap, neo-conservatives such as Charles Murray $^{104}$ and Nathan Glazer ${ }^{105}$ have attempted to extract conclusions about the inherent limits of social policy. Given, however, the attempt of these policies to address long-standing and deeply rooted social problems, given the inherent impossibility in political life of scientific ex ante prediction of the consequences of action, given the need for trial-and-error, and given the weight of tradition working against many of the attempted changes (for instance, sexual and racial inequality), a two or three decade time frame may well be inappropriate for judgments about the overall possibilities for social change within liberal democratic political and economic institutions.

\section{B. WITHOUT LENIN, SMITH OR KEYNES ALTERNATIVE IMAGES AND MEANS OF GOVERNMENT}

With these general considerations in mind, we proceed to examine a number of policy instruments that promise to significantly affect the shape of society. These instruments do not depend upon market forces for their effectiveness nor upon traditional command-and-control instruments.

These instruments evoke a role for the state not well grasped by either traditional market-oriented, individualist views of government, nor traditional collectivist ones. A consideration of these instruments and approaches is necessary if one is to get beyond the contrast between the limits of traditional regulation and the virtues of economic incentives, and to reharness and invigorate utopian energies in the service of real social transformation.

\section{Information, Persuasion and Education}

A pervasive feature of the existing regulatory landscape are policies that mandate disclosure of information about risk, while leaving individuals free to decide whether and to what extent to be subject to the risk in question. ${ }^{106}$ In some instances (pharmaceuticals, etc.) these disclosure requirements may have a "neutral" character, addressing a simple need for information, but in others they are based upon a collective judgment that a particular kind of activity is a menace to health or safety, and that social attitudes towards that activity ought to be changed (e.g. cigarette smoking and alcohol consumption). As Viscusi notes, in selecting which risks to target and how to present

As early as 1927, Julien Benda identified the "soif du resultat immediat" as among the political passions most rapidly adopted by intellectuals in public life: $L a$ Trahision des clercs, $2 \mathrm{e}$ ed., (Paris: Grasset, 1975) at 133. 
them to consumers, the state makes important choices, many of which are not purely instrumental or scientific, but matters of value. The state is neither neutral about the good for its citizens, nor does it impose a single vision of the good on them by coercion. Instead, it plays a role of education or persuasion. ${ }^{107}$

\section{Facilitating Voluntary Social Action by Individuals}

Instead of reinforcing economic self-interest as a motive for human activity, the government may seek to limit or counteract certain risks or costs that face agents who nevertheless have motivations other than material gain for acting in the desired manner. Collective action or transaction and information cost problems (although generally identified with failure of markets or self-interested exchange relationships), may also serve to impede idealistic behaviour. ${ }^{108}$

In the environmental area, an example of where government can address these problems is the "Blue Box" recycling program that exists in Metropolitan Toronto. Residents are provided with a blue plastic box in which to collect bottles and cans for recycling. Once a week the box is collected with other garbage. Although the program is purely voluntary, it enjoys a participation ("compliance") rate of over $80 \% .^{109}$

At one level, the box makes it easy for residents to separate recyclable material from other garbage. Many more people would probably not bother to recycle if they had to take the garbage in question to a common site or pack it separately themselves. At another level, the box is highly visible. A resident who takes down her box on a Wednesday morning sees dozens of others out in the street, and may have the feeling that her own efforts can combine with those of a large number of other individual citizens to "make a difference." Conversely, a resident not inclined to bother participating may be shamed into doing so. It doesn't take long for neighbours on the block to notice that someone is not regularly taking out her box.

\section{Assisting Individuals to Effect Social Change Through Market Behaviour}

Markets themselves may be a powerful instrument for the expression of non-economic preferences. For instance, consumers increasingly demand environmentally safe or friendly products. But collective action problems may impede appropriate consumer monitoring and verification of producers' claims about the environmental safeness of their products or the environmental soundness of their practices. Here, there may be a positive role for government, not to protect the economic interests of consumers or to ensure that their

See R. Howse, "Attachments by Choice: Liberalism and the Problem of Community" (Cambridge, Mass.: LLM Thesis, Harvard Law School, 1990) [unpublished], arguing that public non-neutrality with respect to the good may be consistent with respect for individual autonomy, and indeed required by it. For the orthodox contemporary liberal position, see J. Rawls, "Justice as Fairness - Political not Metaphysical" (1985) 14 Philosophy and Public Affairs 223 and W. Kymlicka, "Liberal Individualism and Liberal Neutrality" (1989) 99 Ethics 883. 
self-interested decisions are informed, but to allow them to express moral preferences through consumption decisions. Kimmel, for instance, suggests that a government agency could give firms and/or products environmental impact ratings and publicize those ratings. ${ }^{.10}$

An example of precisely this kind of regulatory instrument is to be found in the Canadian government's Environmental Choice program, described in detail by David Cohen elsewhere in this volume. "I The program "involves the development of a federal government-owned ECOLOGO, the establishment of product-specific environmental guidelines, and the licensing of private manufacturers, distributors and retailers to use the logo on products which comply with the guidelines." ${ }^{112}$ Although Cohen notes that "the program addresses market failure with market mechanisms rather than through traditional command models of government regulation,"113 the program does involve establishment of precise guidelines and standards, and the kind of complex gathering and analysis of data that the critics of command-and-control regulation implicitly see incentive-based instruments as avoiding. But perhaps more importantly, the environmental guidelines themselves are openly understood to involve not an economic "cost/benefit analysis" but complex choices of value about the relative evil of different kinds of environmental harm. They are evolved through a process of democratic deliberation implicating as many interest groups and public interest groups as can be identified. ${ }^{114}$ Confounding traditional contrasts between collectivist fiat and unimpeded individual choice, this program involves a complex interaction between collective and individual decision making mediated through private associational activity (e.g. interest group membership).

\section{TAKING THE SOCIAL WELFARE STATE BEYOND THE REGULATORY REFORM DEBATE $\cdots$ ASSOCIATION, AUTONOMY AND CARE}

As Gilbert and Gilbert suggest, the focus of the regulatory reform movement on incentives and market-friendly policy instruments in areas such as environmental and occupational health and safety regulation has generated parallel policy prescriptions with respect to welfare reform: "one of the prominent changes in the structure of modern welfare systems involves the related movements toward decentralization, privatization, and commercialization of the social market." 115

J.P. Kimmel Jr., "Disclosing The Environmental Impact of Human Activities: How a Federal Pollution Control Program Based on Individual Decision making and Consumer Demand Might Accomplish the Environmental Goals of the 1970s in the 1990s" (1989) 138 University of Pennsylvania Law Rev. 505.

III. D. Cohen, "Procedural Fairness and Incentive Programs: Reflections on the Environmental Choice Program." Printed in this volume, 544 at 545.

112. $\quad$ bid. at 548.

113. Ibid. at 554 .

114. Ibid. at 564 .

115. N. Gilbert \& B. Gilbert, The Enabling State: Modem Welfare Capitalism in America (Oxford: Oxford U.P, 1989) at 22. 
Among the most prominent and long-standing critiques of government intervention, whether in industrial or social policy, has been its tendency to reduce the self-reliance and independence of individuals and groups and make them dependent upon government activity. Welfare benefits are claimed to make the poor less self-reliant by providing actual disincentives to work. ${ }^{116}$ However, dependency on government is usually contrasted with being independent or autonomous in the marketplace. Some advocates of workfare assume that provision of generous welfare or unemployment benefits simply creates incentives not to work, since persons are naturally lazy. The law promulgating the U.S. Work Incentive Program speaks of a "sense of dignity, self worth, and confidence which will flow from being recognized as a wage-earning member of society." 117 The contrast is between being a ward of the state and leading a fulfilling, independent, self-reliant life in the marketplace.

In fact, this is hardly the choice for many recipients of public assistance. The alternative to dependency on government is dependency on a labour market that may involve working in boring, poorly paid, or dangerous work, with virtually no voice in the conditions and direction of job activity.

A related point is that much thinking about the problem of dependency, especially of the neo-conservative variety, assumes that there is a misfit between the individual and the system. To the extent that individual shortcomings are due to factors seen as beyond self-control such as physical disability, some assistance to the individual may be warranted. But where persons are able-bodied there is inherent suspicion of state dependency, it being assumed that some structure of socialization such as family or school may have failed. ${ }^{118}$ The answer however, may be as much to use government to redesign the system rather than attempt to alter the individual's incentive structure so as to make her "fit in".

Consider also the difference between income supplements to the disabled to insure that they prefer a job below their intellectual potential to welfare, and incentives or rules that actually lead to changes in the technological and human structure of the workplace to accommodate the special needs of disabled people. Government action can lead not just to a lessened dependency on government but also to a greater voice for those who are disadvantaged to shape the system itself. The question of dependency does not boil down to a simplistic choice between public charity and private self-reliance. As Jennifer Nedelsky suggests:

The prevailing (orthodox liberal) conception of autonomy sets alternatives in the context of a false choice; ... It is as though the degree of collective responsibility for, say, the material needs of citizens must result in a corresponding decrease in the autonomy of those receiving the benefits. Such a dichotomy between See C. Murray, supra note 104; N. Glazer, supra note 105; G. Guilder, Wealth and Poverty (New York: Basic Books, 1981).

117. Quoted in I.C. Colby, Social Welfare Policy: Perspectives, Patterns, and Insights (Chicago: Dorsey Press, 1988) at 309.

I1x. See J.Q. Wilson, "The Rediscovery of Character: Private Virtue and Public Policy" (1985) 81 The Public Interest 3. 
autonomy and collective power forecloses a whole range of social arrangements at least to anyone who values autonomy. ${ }^{11}$

I wish to develop in two other directions the theme that redesign and even deepening of government involvement in actively reshaping society, not government retreat, is the better answer to the limits or shortcomings of traditional social regulation.

Inasmuch as individuals can now rely on government, through transfers, to perform what were previously personal and moral responsibilities to look after the disabled, the elderly, etc., it is often said that this sense of moral responsibility will decline, thereby actually increasing the burden that government must bear. Vouchers, food stamps, and welfare payments are a poor substitute for the direct care provided by friends, neighbours, and family. Michael Ignatieff describes the pathos of a society where a sense of community based upon mutual vulnerability has been replaced by a mechanism whereby duties to others become mere transfers between strangers:

My encounters with (the poor) in my neighbourhood are a parable of moral relations between strangers in the welfare state. They have needs, and because they live within a welfare state, these needs confer entitlements rights to the resources of people like me... They are dependent on the state, not upon me, and we are both glad of it. Yet I am also aware of how this mediation walls us off from each other. We are responsible for each other, but we are not responsible to each other. ${ }^{20}$

Ignatieff does not see the answer to this problem as dismantling the welfare state, but, as do some neo-conservatives, he sees a vicious circle: dependency on the state erodes traditional care relationships based upon individual duty and responsibility, and it is in these relationships that persons learn both to help themselves, and in turn to be responsible to others. "Providing communal aid and social protection sometimes runs contrary to encouraging individual responsibility." 121

Some traditional private care-giving systems may have broken down for quite different reasons, relating to changing religious beliefs, social and economic practices, and historical developments peculiar to particular groups (i.e. urban American blacks). ${ }^{122}$ The answer may not be simply to accept dependency as a necessary evil but to direct public resources to identifying and developing new kinds of community and institutional structures that can put "strangers" together and foster mutual care-giving (e.g. lonely, elderly people looking after babies etc., even though there are no blood ties). Communitarian critics of the anonymity of the welfare state tend to identify breakdown of traditional community structures with the breakdown of such structures altogether, thereby inducing a kind of pessimism that may divert attention away from the concrete problems and challenges of encouraging the emergence of new structures. Often this very

J. Nedelsky, "Reconceiving Autonomy: Sources, Thoughts and Possibilities" in A. Hutchinson \& L. Green, eds., Law' and the Community: The End of Individualism (Toronto: Carswell, 1989).

M. Ignatieff, supra note 69 at 10.

N. Gilbert \& B. Gilbert, supra note 115 at 184; see also N. Glazer, supra note 105.

See W.J. Wilson, The Truly Disadvantaged: The Imer City, the Underclass, and Public Policy (Chicago: U. of Chicago Press, 1987). 
pessimism, as well as various collective action and information cost problems, creates a gap between the decline of old community structures and the emergence of new ones. People may continue to identify certain kinds of direct care-giving with kinship ties, even though new social realities suggest an opportunity for mutual care-giving in quite different contexts. Some of the new thinking about the welfare state evidenced in the Ontario SARC Report ${ }^{123}$ sees an important role for the state in the support of new structures, not just in the distribution of transfers.

To see mutual care-giving among freely associated individuals as something that state action can facilitate or provoke is to understand that voluntarism need not begin with, but rather may be a means of creating what Macedo has described as "a citizenry capable of energetic, spontaneous action." ${ }^{124}$ It is also to put in question the view that as soon as government helps people to do something, they will lose the will to do it for themselves. ${ }^{125}$

Another sense in which it has been often argued that social assistance spending programs lead to dependency on government is that these programs have established a "new class" of social workers, welfare bureaucrats, etc. who administer the programs, interfere directly in the lives of recipients, and in some instances are capable of dispensing or withholding benefits on the basis of their opinions about the personal choices of recipients. Quite diverse social thinkers, such as Michel Foucault, Jurgen Habermas, and Nathan Glazer have brought our attention to this aspect of the welfare state. Foucault has documented how the historical development of modern social institutions such as prisons and asylums generated new forms of domination and control, and vested enormous power in the hands of the specialized professions, power exercised in the name of social reform or improvement, and legitimized by the scientific claims of the professions. ${ }^{126}$

According to Habermas, among the core contradictions of the welfare state is that it can either intervene through generalized legal entitlements to monetary relief, (inadequate for reasons discussed above), or through the medium of bureaucratic and therapeutic intervention into the life of the individual. Habermas suggests:

The form of administratively prescribed treatment by an expert is for the most part in contradiction with the aim of the therapy, namely, that of promoting the client's independence and self-reliance. ${ }^{127}$

A number of instruments that do not resemble either the old forms of social policy intervention nor the new "incentive-oriented" instruments (workfare/income supplements) may be appropriate here. Delivery of programs to aid a particular target group can be

Ontario Ministry of Community and Social Services, Transitions (Report of the Social Assistance Review Committee) (Toronto: Queen's Printer, 1988).

S. Macedo, "Capitalism, Citizenship and Community" (1989) 6 Soc. Phil. \& Pol. 113 at 131. 
contracted out to members of the group in question (disabled persons, single-mothers etc.) The government can grant directly, for instance, to women's self-help groups the funding necessary to run shelters for battered women, with minimal direct bureaucratic control of the provision of care. In this way, the dependent or supplicant position of the beneficiary group can be mitigated or reversed. Such an approach also may lead to the creation of new organizations (in response to the opportunity to deliver the services) that can become important structures for mutual support and interdependence. This provides an alternative or at least a counterbalance to dependency on transfers from strangers (the impersonal welfare state), manipulation by professional therapists, or dependency on traditional structures (church, family, private charity), each of which can threaten to impede the path to autonomy.

Protection of welfare rights should focus not only upon enhanced opportunities for judicial or bureaucratic review (which make recipients dependent upon yet another professional elite - lawyers and judges in order to emancipate them somewhat from social workers and welfare enforcers), but also on systemic innovations by which recipients themselves and their support organizations have a direct role in the implementation of policy and delivery of programs. Appeals on welfare benefits, or with respect to decisions by social workers affecting recipients, might be heard by a review board consisting in part of recipients themselves.

After analyzing the consequences of client participation in the development and administration of community action programs in the Los Angeles area beginning in the mid-sixties, Marshall concludes that "leaders for social change... are being created where they did not exist before. ${ }^{128}$ Participation on the boards of these programs marked "a turning point" ${ }^{129}$ in the lives of community representatives. They became citizens, one might say, without first having to become bourgeois. They were able to exercise influence on the shape of the system from a perspective formed outside or on the margins. ${ }^{130}$

In sum, contrary to what might be suggested by the rhetoric of neo-conservative welfare reform advocates, the answer to dependency does not entail a retreat of the welfare state towards the voucher society, or a passive acceptance of a greater role for "private" aid. Government must act to create and reinforce new kinds of social structures through which the disadvantaged can achieve self-empowerment. Casting the debate in terms of choice between highly bureaucratic and interventionist vs. tax and transfers approaches, or between private charity vs. public redistribution, risks losing sight of both the problem and the solution.

D.R. Marshall, The Politics of Participation in Poverty: A Case Study of the Board of the Economic and Youth Opportunities Agency of Greater Los Angeles (Los Angeles: Berkeley, 1971) at 141.

lbid. at 145.

In the case of this particular experiment, Marshall notes that it was not sufficient to bring about short-term basic social change through the amount of influence the disadvantaged representatives were able to bring to bear, its core advantage being the creation of new leaders., ibid. Conclusion. See also, for similar conclusions from more recent studies of other participation experiments, J. Pope, Biting the Hand that Feeds Them: Organizing Women on Welfare at the Grassroots Level (New York: Greenwood, 1989) and S. Hacberle, Planting the Grassroots: Structuring Citizen Participation (New York: Praeger, 1989). 


\section{CONCLUSION: RETRENCHMENT, REFORM OR REVOLUTION?}

In this article, I have attempted to suggest a variety of ways in which it may be said that the idea of a shift from command-and-control to incentive instruments tells only one part of the story about smarter government. Rejection by policymakers committed to strong, progressive government of the new opportunities and important lessons evoked by incentive-oriented developments in regulatory theory and practice would be a serious error. Equally erroneous, however, would be to adopt the idea of incentive-oriented policymaking as a new orthodoxy or dogma, or a panacea or short-cut to smarter government. A sensitivity to incentives should broaden, not narrow, the horizon of policymakers, and certainly not blind them to the complexity of the normative choices as well as the instrument design issues implicated in entertaining such shifts. Moreover, in many contexts command-and-control instruments continue to offer opportunities for better government, and can be altered, evolved or supplemented in light of lessons that may too often be seen as entirely or largely applicable to or indicative of incentive-oriented policy shifts.

Nor should the emphasis on the rules vs. incentives choice in the current debate be seen as demarcating limits to the role of the state in social transformation. There are many ways in which government can help bring about basic social change that neither suggest a return to or intensification of old command-and-control approaches nor an increased reliance on or deference to economically self-interested market behaviour. And it is precisely these alternative approaches that are most promising for advancing the unfinished social agenda of the welfare state through a better reconciliation of care with autonomy and choice with community. 